\title{
MULTIPLE ARTHRITIS DUE TO A FRIEDLANDER BACILLUS.*
}

\author{
GE ORGE F. DICK. \\ (From the Memorial Institute for Infectious Diseases, Chicago.)
}

There seems but little doubt that many cases of chronic multiple arthritis are caused by streptococci and closely related bacteria. The localization of these organisms in the joints when injected into the circulation of experimental animals has been frequently observed. The pathological lesions attending such localization are discussed in the recent articles of $\mathrm{Koch}^{1}$ and Jackson. ${ }^{2}$ Concerning organisms other than streptococci as a cause of chronic multiple arthritis but little is to be found in the literature. The organism concerned in this report was isolated from the following case:

Swedish woman, 25 years old, a few years after coming to America, began to have trouble with the joints of her hands. The joints grew stiff and painful and became enlarged. The disease began insidiously, progressed slowly, and later affected the joints of the toes of both feet, the wrists, the right elbow, and to a slight extent the ankle and shoulder joints. At the time the patient was first seen, the disease had existed about 7 years. The joints most markedly affected were the carpal. These were distended with a fluid of a mucoid consistency, which contained many leukocytes mostly of the round cell type. The fluid was repeatedly found sterile by various cultural methods. The cartilages and the ends of the bones, as shown in the accompanying skiagraph, presented extensive atrophy and some exostosis.

On account of a history of chronic tonsillitis, cultures were made from the tonsils on blood agar plates. Colonies of B. mucosus (Friedländer bacillus) outnumbered all the other colonies on repeated examinations. Several varieties of streptococci were isolated and tested on rabbits in varying doses without producing joint lesions. When injected intravenously the Friedländer bacillus, on the other hand, produced joint lesions in rabbits and dogs in every instance. The organism was very toxic for rabbits and one-fourth of a 24-hour agar slant killed a large rabbit in I $2-24$ hours. In 6 rabbits receiving from one-tenth to one-fifth of 24 -hour cultures death occurred in from $24-72$ hours and in every case the bacilli were found in smear and cultures from the slight exudate in the joints of the animals, purulent pericarditis was found with bacilli present in the pus.

\footnotetext{
* Received for publication December $9, \operatorname{rgr}_{3}$.

${ }^{2}$ Zischr. f. Hyg. u. Infectionskrankh., I912, 72, p. $32 \mathrm{I}$.

- Jour. Infect. Dis., I913, I2, p. $3^{64}$.
} 


\section{Multiple Arthritis Due to a Friedlander Bacillus $\quad$ i 77}

In order to produce more marked joint changes 4 rabbits were given repeated intravenous injections beginning with one-fortieth of a 24 -hour culture and doubling the dose every few days until one-half of a 24 -hour culture was given at a dose. In this way extensive changes in the joint structure with exudation, atrophy, and bone proliferation were produced. Fig. 2 illustrates the changes. In one of the animals,

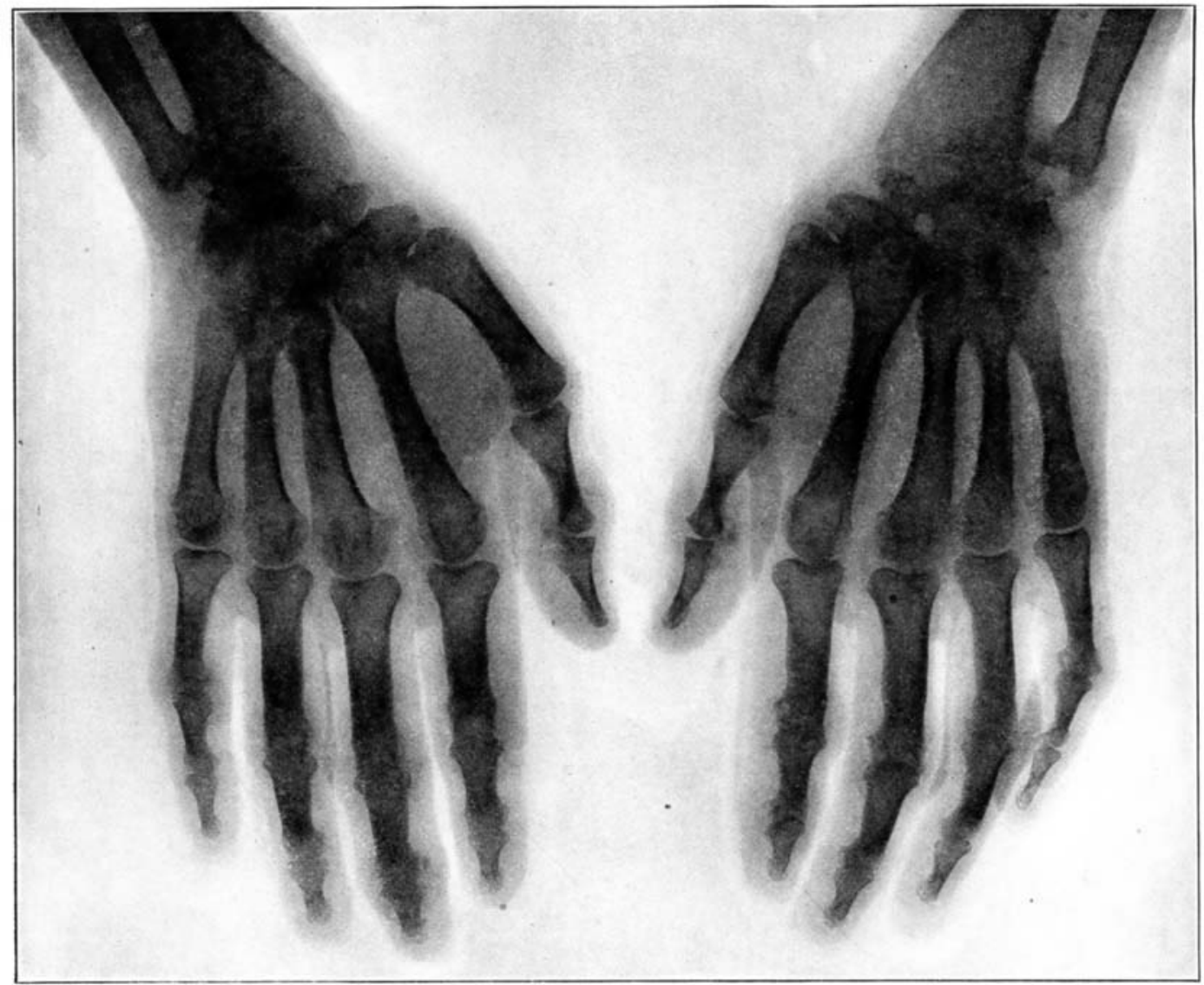

Fic. 1,-Skiagraph of hands showing destruction of cartilage, absorption of bone and, in places, exostoses.

killed $\mathrm{I} z$ days after the last injection, the exudate into the joints was sterile. In the more chronic cases the leukocytes present in the exudate were mostly of the round cell type, while those of the acute cases were of the polymorphonuclear type. The joints affected most markedly were the carpal and phalangeal jcints especially of the forelegs.

The bacillus with which these changes were produced is a gram-negative encapsulated organism, occurring singly and in 
pairs, and forming a heavy transparent slimy growth. A comparison was made with bacilli of similar morphology from other sources. Three other organisms were used, one isolated from a pneumonia lung, one from an acute rhinitis, and one from a chronic pharyngitis. None of these organisms produced joint lesions in

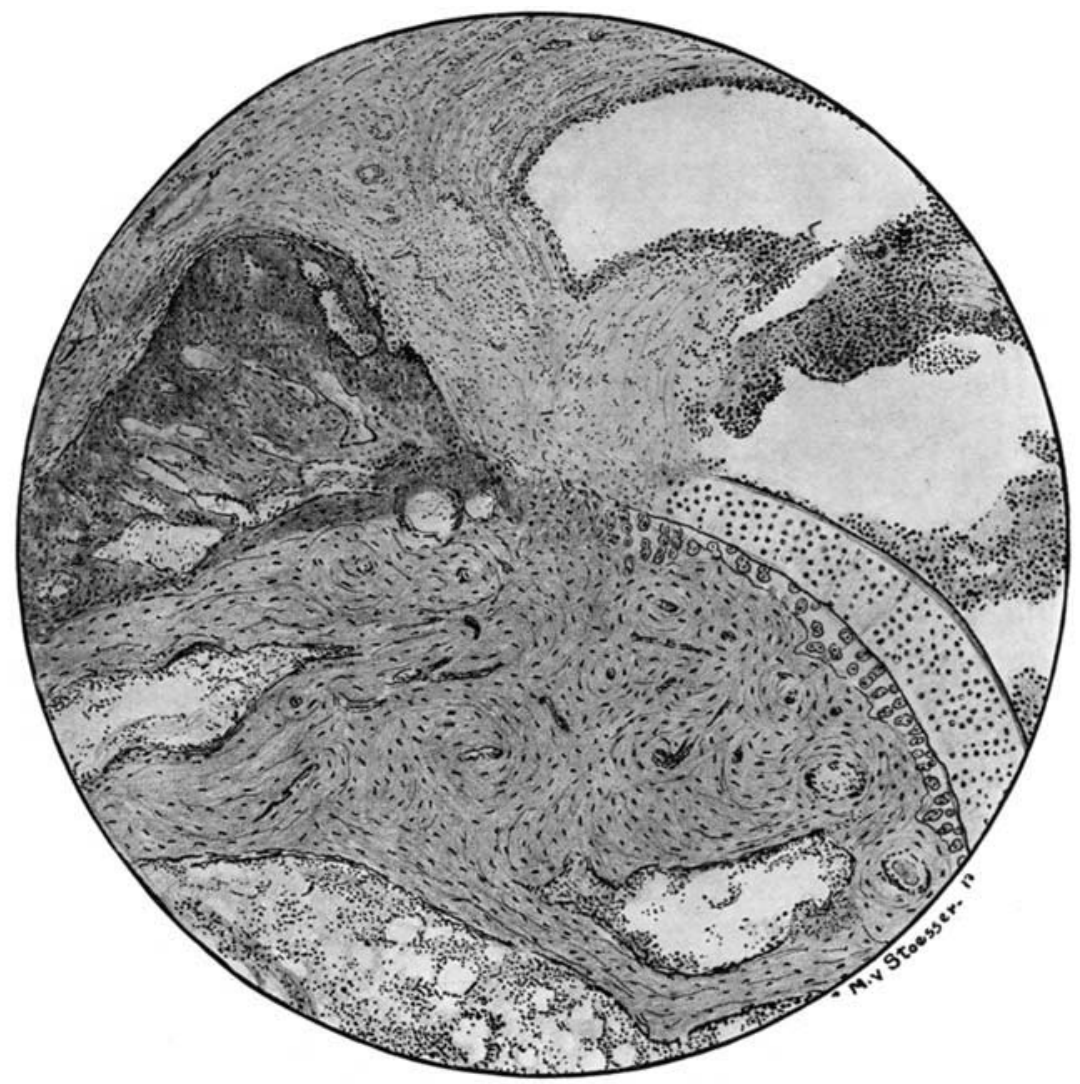

FIg. 2.-Microscopic appearances in chronjc arthritis produced in a rabbit. Note exudation, consisting mostly of round cells, and destruction of cartilage and bone with exostosis.

animals and all were much less toxic. Differences in the powers of fermentation of these organisms are shown in Table $\mathrm{I}$.

Perkins $^{x}$ classifies bacilli of the Friedländer type as follows: I. The aerogenes capsulatus type ferments all sugars with gas. 
II. The $B$. pneumoniae type, ferments all sugars excepting lactose with gas. III. $B$. lactis aerogenes ferments all sugars excepting saccharose. According to this division the bacillus causing arthritis is of type I while the other organisms studied are of type II.

TABLE I.

\begin{tabular}{|c|c|c|c|c|c|c|c|c|}
\hline \multirow{2}{*}{ Media } & \multicolumn{2}{|c|}{ ARthritis } & \multicolumn{2}{|c|}{ Pharyngitis } & \multicolumn{2}{|c|}{ RHINItis } & \multicolumn{2}{|c|}{ Pneumonia } \\
\hline & 24 hrs. & $72 \mathrm{hrs}$. & $24 \mathrm{hrs}$. & $72 \mathrm{hrs}$. & 24 hrs. & 72 hrs. & 24 hrs. & $72 \mathrm{hrs}$. \\
\hline $\begin{array}{l}\text { Dextrose } \\
\text { Mannite } \\
\text { Milk Lit. } \\
\text { Lactose. . } \\
\text { Inulin . . } \\
\text { Gelatin . }\end{array}$ & $\begin{array}{l}\text { Acid-gas } \\
\text { Acid-coag. } \\
\text { Acid-gas }\end{array}$ & 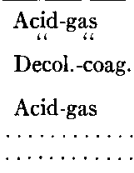 & $\begin{array}{l}\begin{array}{l}\text { Acid-gas } \\
\text { Acid }\end{array} \\
\ldots \ldots \ldots\end{array}$ & $\begin{array}{l}\text { Acid-gas } \\
\text { Acid } \\
\text { Slight acid; } \\
\text { no coag. }\end{array}$ & $\begin{array}{l}\text { Acid-gas } \\
\text { Acid } \\
\text { Decol.; no } \\
\text { coag. }\end{array}$ & $\begin{array}{l}\text { Decol coag. } \\
\text { Acid } \\
\text { Acid } \\
\ldots \ldots \ldots \ldots\end{array}$ & Acid-gas & $\begin{array}{l}\text { Acid-gas } \\
\text { Slight acid; } \\
\text { no coag. } \\
\ldots \ldots \ldots \ldots \\
\ldots \ldots \ldots \ldots\end{array}$ \\
\hline
\end{tabular}

Following a series of injections of killed bacilli increasing in dosage from one million to one billion organisms a marked improvement occurred in the patient, followed, however, by a relapse accompanying an acute bronchitis, tonsillitis, and rhinitis. Following this, further vaecine treatment produced but little effect until the removal of the tonsils after which vaccines were again given with improvement and absorption of exudation which has lasted for about six months. 